\title{
A Synthesis of Psychological Aspects with the Sociological Constrains in Arthur Miller Tragedies
}

Marsela Turku

PhD, Aleksander Moisiu University, Durres, Albania

\section{Abstract}

This paper analyses the amalgam of psychological elements with the social realism where his characters are placed. The paper focuses on the inner conflicts of the characters and points out the literary devices that Miller uses to bring to life. Miller's drama embodies the Freudian concept of human psychological nature and the father-son conflict which is present at his most successful works. These conflicts are evident in "The Crucible," "All My Sons," "The Death of a Commissioner," "View from the Bridge," "After the Fall," and "Descent from Mount Morgan." In the plays where this conflict is not the primary conflict, it serves as a bases where other inner conflicts are grown.

Keywords: Psychological elements, father-son conflict, identity, mythological elements etc.

\section{Introduction}

Psychological drama is as ancient as drama itself. The mystery of the human being and the inner motivation of the individual have been at the centre of Greek dramas since Aeschylus, Sophocles or Euripides. At least five centuries before Christ and before Freud published his psychoanalytic studies, the public saw on stage the tragedy of Oedipus who kills his father and marries his mother, Elektra. However, the influence that modern psychologists and the studies of psychoanalysts such as Sigmund Freud, Alfred Adler and Karl Jung have made a valuable contribution to the development of psychoanalysis which has influenced twentieth-century literature. Many of the writers of the '40s and' 50s relied on these studies to describe the inner world of the characters. The writers described the inner sufferings of the characters and dramatized the conflicts within the being by giving more priority to the inner world than to the outer reality. The method of the stream of consciousness and the flashbacks enabled the writers to make a more detailed analysis of the character's personality. This new stream of realism, often referred to as "psychological realism", gives the playwright the opportunity to stage internal conflicts and darker thoughts. Psychological realism does not stop at just describing what happens, but delves into the inner and psychological dynamics of the character. Arthur Miller is influenced by 
psychological realism and in many of his plays he tries to present on stage the internal conflict of the characters, their duality, the emotional and psychological insecurity that stems from the lack of coherence of their identity. Thus Miller's plays "All My Sons", "The Death of a Commissioner", "View from the Bridge", "The Crucible", "After the Fall", "Broken Glass", "The Price" and "The Last Yankee" are a combination of psychological realism with traditional realism and expressionist techniques with Miller's concept of social drama.

\section{Psychological Realism in Miller's social drama}

Miller presents himself to us as a responsible playwright. To him the human world is not and can never be black and white; the human world is full of psychological unknown, stemming from moral and customary traditions inherited from generation to generation; family relationships, but also the unknown elements related to the "prohibitions" or "permissions" that life enables.

Miller's drama embodies the Freudian concept of human psychological nature: "Every life is two folded. Down in the unconsciousness we exist, in our wholeness we are the past and the present, primitive and civilized man, the turbulent mixture of living beings, the archaic remnants of a wider self-connected with nature, in the clear and

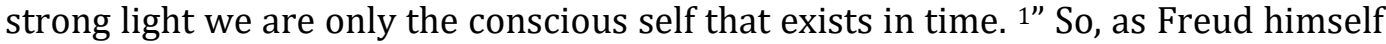
claims, the greatest conflict to be resolved is the psychological conflict within man, where the old instincts temporarily suppressed in the unconscious sleep, but when given the opportunity they unfold unpredictably and aggressively, so they are revealed in the conscious.

In Miller's drama we encounter elements of psychoanalysis. His preferred subject is a man persecuted by the past, self-sacrificed in the present to defend ideals or morals almost unattainable in the time in which he lives, while the future is almost nonexistent, unreal and projection of the past or its revival. Bigsby observes that: "while the direct tension in his plays displayed the emotional and psychological truths of his characters, as a Freudian analyst could do by digging into the background and indirectly into sexual and social relations, this effect of discovery of the naked self aims to highlight the psyche of a culture. " 2

Freud emphasizes the importance of childhood, in the same way Miller artistically addresses to the past, social conditions, rites or traditions to penetrate to the psyche of the character who cannot be understood and much less interpreted without this layer of his personality. Willie Loumen's life is closely linked to his family's past, but also to that of the American culture. His earliest memory relates to his stay in a freight car in South Dakota, where his father made and sold flutes as they moved from place to place. This is also the ideal world for him, a world in which you are free to move, to

1 http://psychology.about.com/od/theoriesofpersonality/a/consciousuncon.htm

2 Christopher Bigsby, A Critical Introduction to Twentieth Century American Drama, Vol. II, Cambridge University Press, 1984, p. 135. 
live with what you produce and your identity is forged by your actions and is imposed by a profession or a product with which he finds no organic bonds. In his unconsciousness this is the ideal world in which he intends to live. But the past is not always so idyllic, so rosy. Willie Loumen himself as a child is the victim of a family betrayal; the father abandons him and his mother and leaves for Alaska. His brother Ben, who is leaving for Africa, is doing the same. Thus Willie was born into a changing world, in an era where material pressure had begun to unravel the pastoral myth as cities began to urbanize. Willie's character cannot be interpreted without this temporal and spatial stratification of the former America.

Miller's main characters are motivated by deep-rooted ideas to justify themselves. They shape their identity through extreme actions of self-affirmation. The conflict between father and son precedes revolutionary conflicts in tragedy. At first the child asserts his independence after facing an intolerable paternal authority. Later this hero, grown both in age but also in art, leads the protest against the coercive forces more powerful than the paternal power ${ }^{1}$. The father-son conflict is at the heart of Miller's most successful work, but this conflict comes into play on a psychological level, through the "Oedipus complex" and the "Electra complex." In "The Lucky Man" this conflict is implied, however in "The Death of a Commissioner", "All My Sons", "View from the Bridge" on this conflict there are developed other topics of drama. This relationship unites the present with the past, desires and ambitions are put before the test. "Therein lies the place of identity, anxiety, of conflicting values, of an ambiguous and guilty love 2 ."

Miller unites in a three-dimensional projection the world of his characters, where the first dimension is the unconscious deeply engraved in the past, the second dimension that of the experiences and feelings of the moment, while the third dimension is the chaotic union of the first two dimensions, of the past with the present, a union which causes spiritual and psychological confusion from which neuroses originate, but also tragic actions as is common with Miller characters. These characters often also face multiple conflicts, first with themselves, inherited instincts which have not been fully combated and which lead them astray, committing adultery (the case of Willie Loumen, John Procter), causing collective murder (the case of Jim Keller), inclining to incest ("View from the Bridge "), deceiving the whole society for revenge (Abigail's case) and many other iniquities; and secondly they face the social environment ("View from the Bridge", "All My Sons", "Broken Glass"); and third, with the ideal for which they continually strive, for self-fulfilment, economic and social success, painfully embodied in the American dream, to that "green" light that Willy, like Gatsby, would always covet.

1 Christopher Bigsby, Arthur Miller, A Critical Study, Cambridge University Press, 2005, p. 147-148. 2 Datar Unanati, "Psychoanalytic Study of the Plays of Arthur Miller", International Journal on English Language and Literature, Vol. 1, No. 1, p. 24. 
The interaction of Id, Superego and Egos is evident in the inner dilemmas and psychological issues of the characters. On one hand, we also have external pressure on the individual. This pressure involves forces outside the individual, such as social, family, or temporal. These conflicts are evident in "The Crucible," "All My Sons," "The Death of a Commissioner," "View from the Bridge," "After the Fall," and "Descent from Mount Morgan." John Procter is in conflict with himself and society which requires him to act according to its rules even to the detriment of his reputation. Willie Loumen faces himself and society, deceived by illusions that society itself had presented to him as values. Chris Keller is also in threefold conflict, with himself, his family and society when he discovers the crime committed by his father and the reason why he committed it. Edi Carbone's incestuous passion for Catherine, which he constantly tries to suppress, will lead him to destruction. The drama seems to be built on the discovery of two mysteries, that of Edi's incestuous desire for the granddaughter and the hiding of two Italian immigrants in his house. The gradual discovery of these two secrets will also provoke the tragic end of Edi.

The tragedy of "View from the bridge" is built on a host of symbols such as high heels and short skirts that Catherine wears not only in protest against Edith, but also as a symbol of seduction and power she men. A boxing match becomes the masking of a strong sense of hostility; a game in the waiting room has upon turns into a threat and warning. It seems that every "action takes on a double meaning. "Increased tension is expressed less in discourse and more in action, as in this desperate context silence is the only way through which feelings can be expressed or articulated. ${ }^{1 "}$ The Brooklyn Bridge is another powerful and versatile symbol in drama. It evokes the division between the two cultures, the American and the Italian; at the same time it is also a symbol of economic achievement and awakens the beautiful American dream of these immigrants.

In some dramas the mystical and mythological elements perform the function of symbolic subtextual elements which help us to deconstruct the spiritual and psychological state of the characters; just to mention the house of Willie Lomen in "The Death of a Commissioner," which shows the spiritual ruin of his characters, or the symbolic character of Uncle Ben; repressed desires are projected into conversation with unreal characters, like Willie with his brother Ben; Abigail in The Crucible talks to the world beyond; dead people appear to Mr. Peter.

To sum it up, Miller's drama embodies the Freudian concept of the human psychological nature: "Every life is twofold. Down in the unconscious we exist, in our wholeness we are the past and the present, primitive and civilized man, the turbulent mixture of living beings, the archaic remnants of a wider self-connected with nature, in the clear and strong light we are only the conscious self that exists in time. "So, as Freud himself claims, the greatest conflict to be resolved is the psychological conflict within man, where the old instincts temporarily suppressed in the unconscious sleep,

1 Christopher Bigsby, Arthur Miller: A Critical Study, Cambridge University Press, 2005, p. 190. 
but when given the opportunity they unfold unpredictably and aggressively, so they appear in the reality.

\section{Bibliography}

[1] Christopher Bigsby, A Critical Introduction to Twentieth Century American Drama, Vol. II, Cambridge University Press, 1984

[2] Christopher Bigsby, Arthur Miller, A Critical Study, Cambridge University Press, 2005.

[3] Datar Unanati, "Psychoanalytic Study of the Plays of Arthur Miller", International Journal on English Language and Literature, Vol. 1, No. 1, p. 24. 